\title{
相対発育からみたスピードスケート選手の滑走能力と 大腿部の筋厚及び無酸素性パワーの発達
}

\author{
熊川大介角田直也
}

\section{BIOLOGICAL GROWTH AND DEVELOPMENT IN SKATING PERFORMANCE, MUSCLE STRUCTURE AND ANAEROBIC POWER OUTPUT CAPACITY IN MALE AND FEMALE JAPANESE SPEED SKATERS}

\author{
DAISUKE KUMAGAWA and NAOYA TSUNODA
}

\begin{abstract}
The objective of this study was to examine biological growth and development in skating per. formance by focusing on thigh muscle thickness and anaerobic power output capacity in Japanese speed skaters. One hundred thirty-three male and 96 female skaters aged from 10 to 22 years old were tested in this study. The anterior (MTA) and posterior (MTP) thicknesses of the thigh muscles were measured by the B-mode ultrasonic method. Maximal anaerobic power output capacity (MAP) was determined using a bicycle ergometer. The mean $500 \mathrm{~m}$ skating velocity (SV), calculated from recently attained individual best times, was used as a measure of skating per. formance. These parameters, along with height, were plotted on a logarithmic graph to obtain the allometric equation $y=b x^{a}$, where " $a$ " is a growth index.

There were two sharp bends in the graph showing the relationships between MTA, MTP, MAP, SV and body height in both males and females. The growth indexes "a" between the first and second changing points in all the above relationships were observed to be larger than the other phases. Ranges of body height between the first and second changing point in muscle thicknesses (MTA, MTP) ranged from $152.2-154.8 \mathrm{~cm}$ to $168.1-168.3 \mathrm{~cm}$ in males, and from $142.8^{-}$ $144.9 \mathrm{~cm}$ to $154.4-157.6 \mathrm{~cm}$ in females. The ranges of MAP were from $139.8 \mathrm{~cm}$ to $166.8 \mathrm{~cm}$ in males, and from $138.8 \mathrm{~cm}$ to $157.8 \mathrm{~cm}$ in females. However, the height ranges of $\mathrm{SV}$ were from $147.4 \mathrm{~cm}$ to $167.8 \mathrm{~cm}$ in males, and from $142.2 \mathrm{~cm}$ to $153.2 \mathrm{~cm}$ in females.

From these results, it was suggested that accelerated development of skating performance and anaerobic power output capacity begins earlier than muscle structural development in speed skaters.
\end{abstract}

(Jpn. J. Phys. Fitness Sports Med. 2008, $57: 119 \sim 130$ )

key word: Speed skater, Biological growth and development, Skating performance

I . 緒言

これまでに，国内外のスピードスケート選手の体 力的特性に関する研究の多くは, 一流選手や成人選 手における筋の形態的及び機能的特徵を明らかにし た報告が主である．弚れらの報告によると，スピー ドスケート選手における全身の骨格筋量は, 一般成 人に比べて著しく多く ${ }^{24)}$ ，かつ競技成績の優れる 選手ほど筋量の発達が著しいことが明らかにされて (る ${ }^{27)}$.また，スポーツ選手の体肢組成について

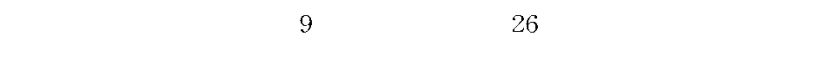

とも大腿筋群の横断面積が他のスポーツ選手と比較 して大きく，中でも外側広筋の発達が著しいことを 明らかにしている，従って，スピードスケート選手 における筋の形態的特徵としては, 特に下肢筋群の 発達が著しいと考えられる.このような筋の量的な 発達は，発揮される力やパワーにも影響を及ぼす． Rajala et al. ${ }^{25)}$ は, 男子スピードスケート選手の膝 関節伸展トルクや角速度及びパワーを各関節角度に ついて測定している，弚の結果，関節トルク及びパ ワーは, 全ての角度において一般成人よりも高い値 を示し, さらに弚の出力特性は水上滑走中のものと 
ほぼ類似するという．また, Kanehisa et al. ${ }^{11)}$ は, スピードスケート選手は一般成人に比して膝伸展筋 群における等速性筋出力の持続能力において優れる ことを明らかにしている.さらに, Geijsel et al. ${ }^{6)}$ の報告では，自転車の全力ペダリング中のパワーと 水上滑走中のパワーとの間に有意な相関関係が認め られている. 従って, スピードスケート選手は下肢 における高いパワー発揮能力を有し，さらに光れら の能力が競技成績に直接的に関与するといえる .

一方，このような体力的特性を有するまでの過程 について, 発育・発達的観点から検討した報告は少 ない. de Koning et al. ${ }^{3)}$ は 5 年間の縦断的研究か ら，好成績を収めた成人スピードスケート選手は， 16歳以降で自転車ペダリング中のパワーが著しく増 加したことを報告している．また，根本たち ${ }^{21) や ~}$ Nemoto et al. ${ }^{23)}$ は, 10歳から18歳におけるジュニア 選手の除脂肪体重や単発的な筋出力の年齢推移を示 し, 同年代の一般児童及び生徒と比較している. 光 の結果，男女ともに16歳以降の年齢において有意な 差異か認められている . 従って , スピードスケート トレーニングの効果は, 特に思春期以降の男女にお いて顕著に現れるものと推察できる．

しかしながら，10歳代における男女を対象として 暦年齢的な発育・発達の程度を明らかにする場合， 身体発育の個人差や性差といった生物学的な成熟度 の影響を考慮した手法でなければならないと考えら れる，暦年齢という時間的な因子ではなく，生物学 的年齢の指標である身長を基準として, 体力の発達 を相対的に評価する方法としては, アローメトリー 式 $\mathrm{y}=\mathrm{bx} \mathrm{x}^{\mathrm{a}}$ が主として用いられている.Asmussen and Heebooll-Nielsen ${ }^{1)}$ は, 身長と身体各部の発育 が幾何学的な関係にあるものと仮定し, 光の理論值 と実測值の比較を行っている. 兴の結果, 身長に対 して四肢の筋力や跳躍高及び走速度の発達速度は, 理論値よりも高い值を示すことを報告している．ま た，金久たち ${ }^{10)}$ は同樣の手法により，身長と体肢 の筋断面積との関係について検討した結果, 男女 ともに両者の関係は 2 箇所の変移点を持つ 3 相の直 線で表されることを報告している，一方，スポーツ 選手の場合, 筋形態及び機能の発達は, 専門種目卜 レーニングの影響を大きく受けることは周知の事実 である，従って，身長と体力的要素との関係におけ る発育速度や変移点がみられる時期が, 一般児童及
び生徒の場合とは異なることが予想される .さらに， 身長とスピードスケート滑走能力の関係についての 知見はこれまで得られていない．

乥こで本研究では, 身長の発育に伴うスピードス ケート滑走能力の発達と大腿部の筋厚及び無酸素性 パワー発揮能力との関係を明らかにする事を目的と した。

$$
\text { II. 方法 }
$$

\section{A. 被検者}

本研究の被検者は, 群馬県スケート連盟及び嬬恋 スケートクラブに所属する10歳から 22 歳までのス ピードスケート選手，男子133名，女子96名の計229 名を対象とした，測定に先立って各被検者には，本 研究の目的, 測定の内容と午の安全性について十分 説明した後, 被検者及び关の保護者から測定参加へ の任意による同意を得た .なお，本研究では被検者 の競技レベルを確認するために, 小学生, 中学生 , 高校生及び大学生一成人選手におけるスピードス ケート競技 $500 \mathrm{~m}$ 種目の国内最高記録(小学生は県 内最高記録，大学生一成人選手は日本記録)に対する 被検者の $500 \mathrm{~m}$ 最高記録の比率 ${ }^{13)}$ を算出した結果， 男子は約 $84.7 \%$ から $90.4 \%$ ，女子では約 $85.1 \%$ から 89.1\%の範囲内であり, 各年代ともにほぼ同樣の競 技レベルを有しているものと判断した . また , 小学 生では県内最高記録保持者, 中学生では全国大会準

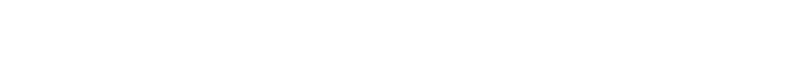
含まれていた . 本研究では, 男子の身長 $130 \mathrm{~cm}$ か ら $185 \mathrm{~cm}$ まで, 女子では $130 \mathrm{~cm}$ から $165 \mathrm{~cm}$ まで を光れ艺れ $5 \mathrm{~cm}$ 毎の階級に分けた . 各身長階級に おける被検者数，平均年齢及び身体的特性について は, 平均値と標準偏差值で Table 1 に示した .

また, 本研究は国士舘大学体育学部研究倫理委員 会の審査を受けて実施した .

\section{B. 身体組成}

各被検者の身長は身長計を用いて計測した。ま た，体重及び除脂肪体重(FFM) は，体内脂肪計 (BODY FAT ANALIZER, TBF-110, TANITA 社製) を用いて両足間から 4 電極のインピーダンス法によ り測定した . 
Table 1. Number of subjects and physical characteristics with body height.

\begin{tabular}{|c|c|c|c|c|c|}
\hline & $\begin{array}{l}\text { Body height } \\
\quad(\mathrm{cm})\end{array}$ & $\mathrm{n}$ & $\begin{array}{l}\text { Age } \\
\text { (yrs) }\end{array}$ & $\begin{array}{l}\text { Body height } \\
\text { (cm) }\end{array}$ & $\begin{array}{c}\text { Body mass } \\
(\mathrm{kg})\end{array}$ \\
\hline \multirow{11}{*}{ Male } & $130-134.9$ & 3 & $11.3 \pm 0.6$ & $132.9 \pm 1.0$ & $28.5 \pm 3.8$ \\
\hline & $135-139.9$ & 9 & $11.1 \pm 1.1$ & $137.3 \pm 1.8$ & $31.1 \pm 3.2$ \\
\hline & $140-144.9$ & 7 & $10.7 \pm 0.8$ & $141.4 \pm 1.4$ & $32.5 \pm 2.6$ \\
\hline & $145-149.9$ & 6 & $11.5 \pm 1.0$ & $146.6 \pm 1.4$ & $37.7 \pm 2.2$ \\
\hline & $150-154.9$ & 6 & $13.0 \pm 0.9$ & $152.7 \pm 1.3$ & $41.6 \pm 4.7$ \\
\hline & $155-159.9$ & 7 & $12.7 \pm 0.8$ & $157.2 \pm 1.4$ & $44.8 \pm 2.7$ \\
\hline & $160-164.9$ & 12 & $14.0 \pm 1.2$ & $162.8 \pm 2.0$ & $53.1 \pm 5.5$ \\
\hline & $165-169.9$ & 38 & $16.4 \pm 2.0$ & $167.3 \pm 1.2$ & $61.2 \pm 6.5$ \\
\hline & $170-174.9$ & 26 & $17.4 \pm 2.1$ & $172.5 \pm 1.5$ & $63.2 \pm 5.5$ \\
\hline & $175-179.9$ & 12 & $17.8 \pm 2.4$ & $177.8 \pm 1.6$ & $66.6 \pm 6.6$ \\
\hline & $180-184.9$ & 7 & $19.9 \pm 1.8$ & $182.0 \pm 2.8$ & $75.1 \pm 4.4$ \\
\hline \multirow{7}{*}{ Female } & $130-134.9$ & 3 & $10.0 \pm 0.0$ & $134.1 \pm 0.3$ & $30.4 \pm 0.6$ \\
\hline & $135-139.9$ & 4 & $10.0 \pm 0.0$ & $138.3 \pm 2.2$ & $30.7 \pm 1.5$ \\
\hline & $140-144.9$ & 7 & $11.0 \pm 1.0$ & $142.6 \pm 1.7$ & $35.0 \pm 3.6$ \\
\hline & $145-149.9$ & 10 & $12.2 \pm 1.5$ & $148.1 \pm 1.5$ & $39.1 \pm 6.6$ \\
\hline & $150-154.9$ & 24 & $14.1 \pm 2.6$ & $152.5 \pm 1.7$ & $46.9 \pm 7.2$ \\
\hline & $155-159.9$ & 31 & $16.0 \pm 2.8$ & $158.0 \pm 1.3$ & $54.3 \pm 6.4$ \\
\hline & $160-164.9$ & 17 & $15.9 \pm 2.3$ & $162.1 \pm 1.3$ & $56.5 \pm 7.1$ \\
\hline
\end{tabular}

Values are expressed as mean \pm S. D.

\section{C. 筋厚の測定}

大腿部における筋厚は，超音波測定装置(Echo Camera SSD-900CL, ALOKA 社製)を用いて，超音 波周波数 $7.5 \mathrm{MHz}$ で測定した . 測定部位は，右側 の大腿部前面 (MTA)及び後面(MTP)であり, 大腿 長の $50 \%$ に相当する位置を乥れ光れ計測した．本研 究における筋厚値は, 石田たち ${ }^{7)}$ 方法に従い, 皮 下脂肪組織と筋組織の境界を示す反射波から大腿骨 までの距離を乥れ光れ筋厚とした．なお，大腿長は 大転子から脛骨点までの距離を巻尺を使用して測定 した。

\section{D. 無酸素性パワーの測定}

無酸素性パワーの測定は, 宮下 ${ }^{16)}$ の方法に従い， 電磁ブレーキ式自転車エルゴメーター (POWER MAX VII, COMBI社製)を使用して, 無酸素パワー テストを行った。即ち, 各被検者には通常のトレー ニング前に実施しているウォーミングアップの後 に, 負荷を変えることによる10秒間の全力ペダリン
グを 2 分間の休賏をはさんで 3 回行わせた . 第 1 の 負荷は体重 $59 \mathrm{~kg}$ 以下が $3 \mathrm{kp}, 60 \sim 70 \mathrm{~kg}$ が $4 \mathrm{kp}$, $80 \mathrm{~kg}$ 以上が $5 \mathrm{kp}$ というように，被検者の体重に よって設定され，第 2 及び第 3 の負荷は前試技のペ ダル回転数に応じて漸増される .この 3 回の全力ペ ダリングより得られた負荷と最大ペダル回転数との 直線から推定されたパワーの最高値である最大無酸 素パワー值(MAP)を個人值として採用した .

\section{$E$. 滑走能力}

滑走能力としては, 測定年度における公式競技会 で記録された $500 \mathrm{~m}$ 最高記録を秒速に変換した平 均滑走速度(SV)で評価した。

F．アローメトリー式の算出

アローメトリー式 $\mathrm{y}=\mathrm{bx}^{\mathrm{a}}$ (両辺の対数をとると $\log \mathrm{y}=\log \mathrm{b}+\mathrm{a} \log \mathrm{x})$ 及び変移点の算出については 金久たち(1) や森下 ${ }^{(7)}$ の方法に従った . 即ち，各身 長階級における測定值の平均值を両対数グラフ上に 
プロットし，複数の身長階級間で最小自乗回帰し， $\log \mathrm{y}=\log \mathrm{b}+\mathrm{a} \log \mathrm{x}($ 身長を $\mathrm{x})$ を求めた .なお， 本研究の全ての関係における相関係数は 0.5 以上で あった . また, 複数の直線で両者の関係が表される 場合には，隣接する直線の交点に相当する身長を変 移点とした．アローメトリー式における b あるい は $\log \mathrm{b}$ は直線の位置を示す值であり, 発育・発達 という観点からするとほとんど意味を持たない . 一 方 “" a” は直線の勾配を表しており, 発育速度の高 低を示す係数とされている(7).

また， $\mathrm{x}$ と $\mathrm{y}$ が等速度で成長する場合には, $\mathrm{a}=$ 1 と表されることになる．また，y のほうが $\mathrm{x} よ$

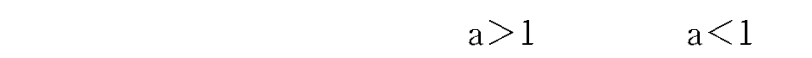
あれば $\mathrm{y}$ の方が劣成長であることを意味する．
Table 2. Correlation coefficients between skating velocity and muscle thicknesses and maximal anaerobic power output capacity in male and female skaters.

\begin{tabular}{lll}
\hline & Male & Female \\
\hline MTA & $.437^{*}$ & $.422^{*}$ \\
MTP & $.438^{*}$ & $.208^{*}$ \\
MAP & $.769^{*}$ & $.667^{*}$ \\
MAP·FFM ${ }^{-1}$ & $.738^{*}$ & $.709^{*}$ \\
\hline
\end{tabular}

MTA : Anterior thigh muscle thickness. MTP : Posterior thigh muscle thickness. MAP: Maximal anaerobic power. FFM : Fat free mass. ${ }^{*}$ indicates significant correlation coefficient $(p<0.05)$.
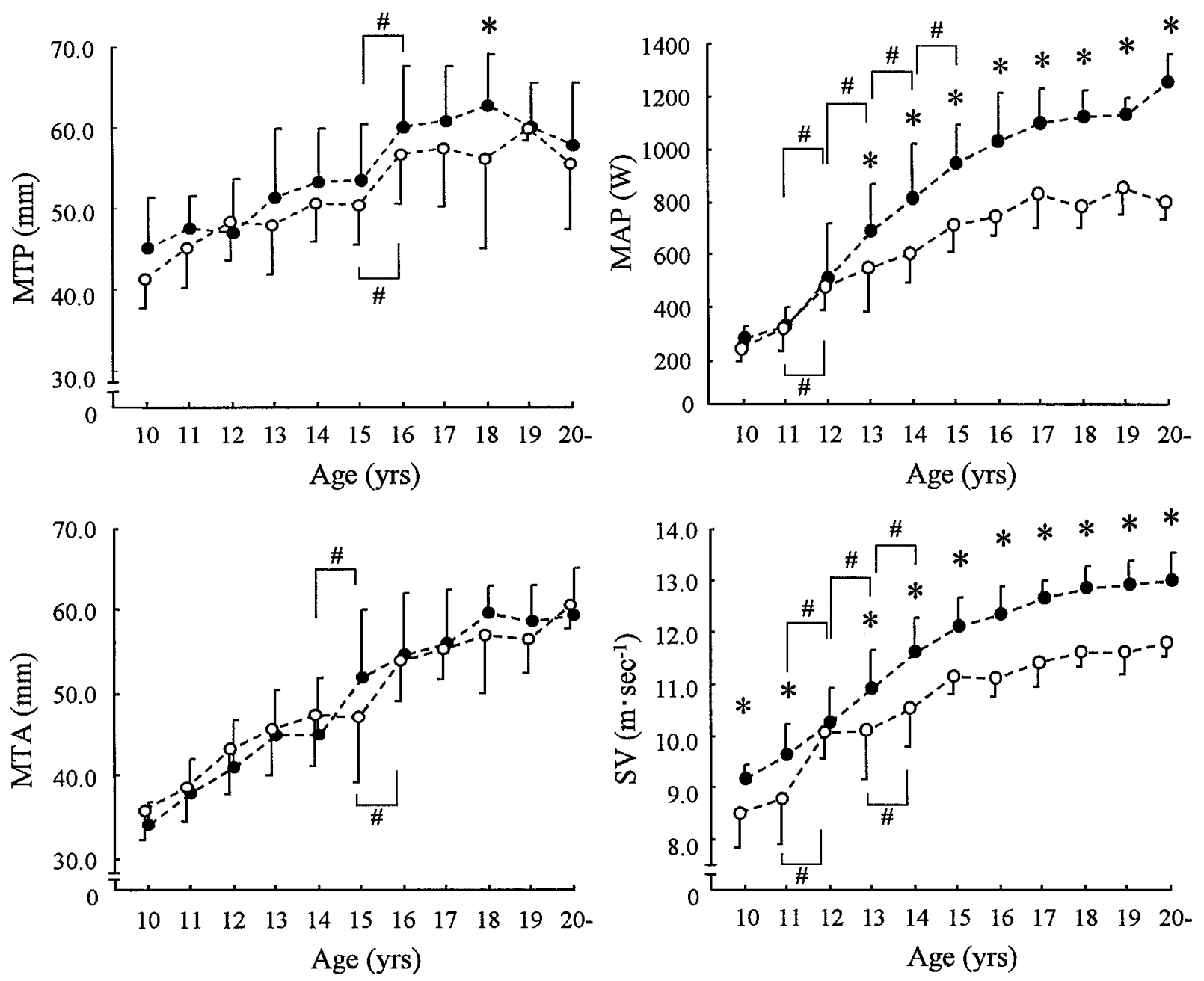

Fig. 1. Age-related changes in anterior (MTA) and posterior (MTP) thigh muscle thicknesses, maximal anaerobic power (MAP) and skating velocity (SV) in male and female speed skaters. : Males. $\bigcirc^{----} \bigcirc$ : Females. ${ }^{*--}$ indicates significant gender difference $(\mathrm{p}<0.05)$. \# indicates significant difference between age groups $(\mathrm{p}<0.05)$. 


\section{G. 統計処理}

本研究における相関係数は，すべて年齢を除去し た偏相関によって求めた。また, 筋厚, 無酸素性パ ワー及び滑走速度におよぼす年齢と性の影響につい ては二元配置分散分析によって調へ, 各年齢群間及 び男女間における有意差は多重比較検定によって検 定した。いずれも，有意水準を $5 \%$ 末満 $(\mathrm{p}<0.05)$ とした。

$$
\text { III. 結果 }
$$

A. 滑走能力と筋厚及び無酸素性パワーとの関係 Table 2 は, 滑走能力と筋厚及び無酸素性パワー の関係について男女別に示したものである.SV と MTA との間には, 男女とも, 弚れぞれ有意な相関 関係(男子 : $\mathrm{r}_{\mathrm{xy} \cdot \mathrm{z}}=0.437$, 女子 : $\mathrm{r}_{\mathrm{xy} \cdot \mathrm{z}}=0.422, \mathrm{p}$ $<0.05)$ が認められた . また, SV と MTP との間に ついても，弚れ光れ有意な相関関係(男子: $r_{x y \cdot z}=$ 0.438 ,女子 : $\left.r_{x y \cdot z}=0.208, p<0.05\right)$ が認められた . MAP 及びFFM あたりの MAP と SV との関係に ついて同樣に，男女とも关れ午れ有意な相関関係 (MAP 男子 : $r_{x y \cdot z}=0.769$, 女子 : $r_{x y \cdot z}=0.667$, $\mathrm{MAP} \cdot \mathrm{FFM}^{-1}$ 男子 : $\mathrm{r}_{\mathrm{xy} \cdot \mathrm{z}}=0.738$ ，女子 : $\mathrm{r}_{\mathrm{xy} \cdot \mathrm{z}}=$ $0.709, \mathrm{p}<0.05)$ か認められた .

\section{B. 年齢に伴う筋厚, 無酸素性パワー及び滑走能} 力の変化

Fig. 1 は, 各年齢における MTA , MTP , MAP 及 びSV の平均値を男女で示したものである.MTA は，性の主効果及び交互作用に有意な差は認められ なかったが，年齢では有意な差異か認められた . ま た，MTP では，交互作用は有意な差が認められな かったが, 性及び年齢における主効果には有意差が 認められた . 男子における MTA の值は，10歳から 約18歳まで, 女子では20歳代まで増加する傾向がみ られ，隣接する年齢間で有意な差異か認められたの は, 男子の14歳と15歳間及び女子の15歳と16歳間で あった．また, MTP の值は, 男女ともに15歳と 16 歳の間で有意な差異が認められたが, 乥れ以降の年 齢ではほぼ一定の值を示した . また, 筋厚の值は, 18歳の MTP において男子が女子よりも有意に高い 値を示すが, 光れ以外の年齢においては両部位とも に有意な男女差は認められなかった，一方，MAP は性及び年齢における主効果及び交互作用に有意な
差異が認められた . 男子の値は, 11歳から15歳まで 各年齢間に著しい増加が認められた . 女子では11歳 と12歳間において有意な差異か認められたのみで， それ以降は17歳まで緩やかな増加傾向を示した．ま た，男女ともに16歳以降の年齢では各年齢群間に有 意な差異は認められなかった . 男女差をみると，14 歳以降の年齢において男子が女子より有意に高い值 を示した。

$\mathrm{SV}$ は，年齢及び性の主効果には有意な差が認め られたものの, 交互作用は認められなかった . SV の值は男女ともに年齢に伴って20歳代まで増加する 傾向がみられるが, 特に男子の11歳から15歳の各年 齢間及び女子の11歳と12歳及び14歳と15歳間では著 しい増加が認められた，一方，男女差についてみる と，10歳と11歳及び13歳以降の各年齢において男子 が女子より有意に高い値を示した .

\section{C. 身長と筋厚, 無酸素性パワー及び滑走能力と の関係}

Fig. 2,Fig. 3 及びFig. 4 は , 各身長群における MTA，MTP，MAP 及び SV の平均值を乥れ光れ対 数グラフ上にプロットしたものである.身長と各項 目の関係は, 光れ光れ 2 箇所の変移点が認められ男

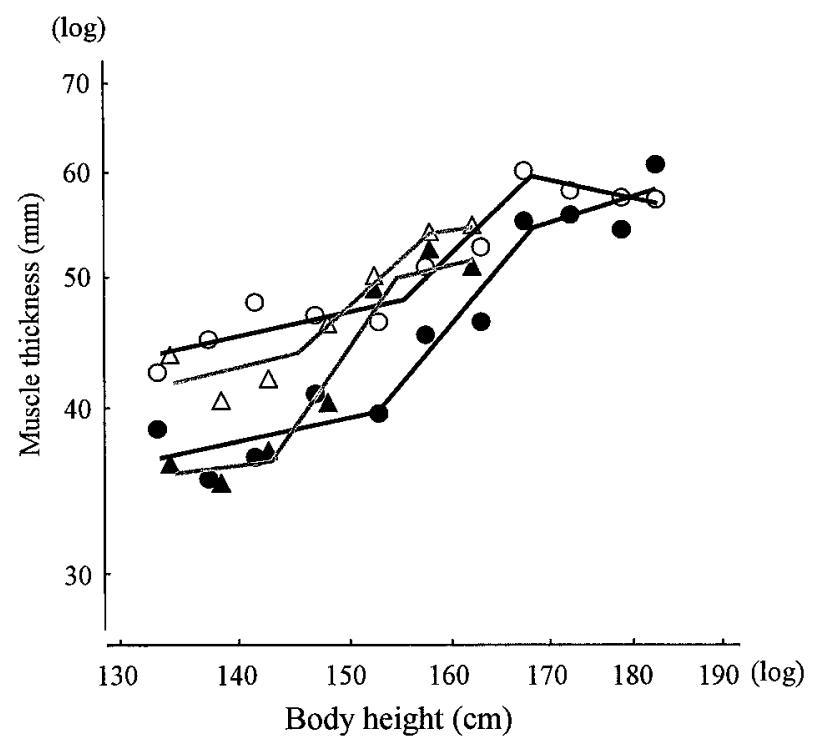

Fig. 2. The relationships between thigh muscle thicknesses and body height in male and female speed skaters. : Anterior thigh muscle thickness in males. $\bigcirc$ : Posterior thigh muscle thickness in males. - : Anterior thigh muscle thickness in females. $\triangle$ : Posterior thigh muscle thickness in females. 


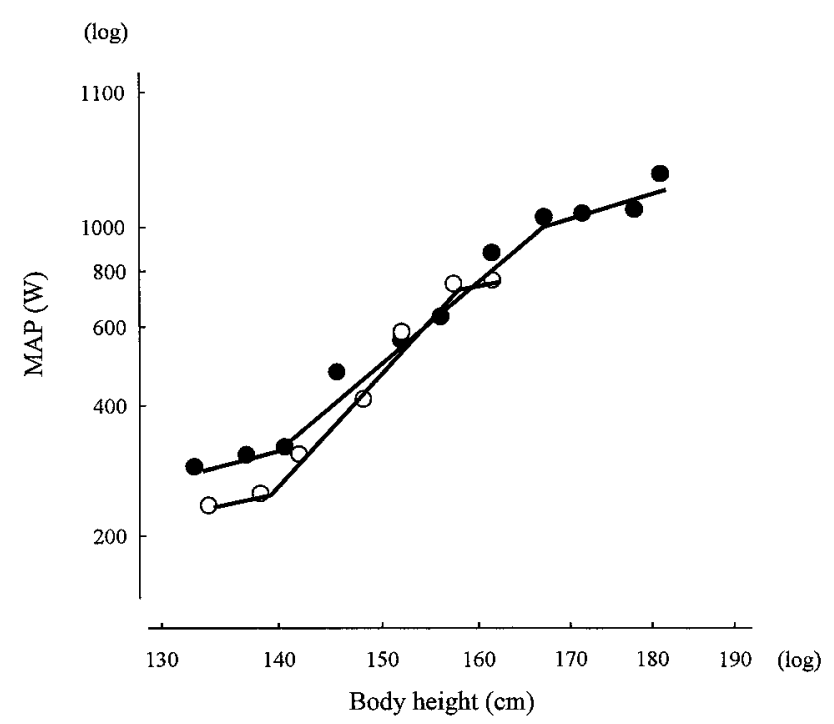

Fig. 3. The relationships between maximal anaerobic power and body height in male and female speed skaters. - : males. $\bigcirc$ : females.

女ともに 3 相の直線で表された .

各項目における第 1 及び第 2 変移点に相当する身 長は, Table 3 に示したとおりである．男子の MTA と MTP における第1 変移点は, 身長 152.2 $\mathrm{cm}$ と $154.8 \mathrm{~cm}$ ，女子では身長 $142.8 \mathrm{~cm}$ と 144.9 $\mathrm{cm}$ で認められた . また，第 2 変移点に相当する身 長は,男子で $168.1 \mathrm{~cm}$ と $168.3 \mathrm{~cm}$,女子では 154.4 $\mathrm{cm}$ と $157.6 \mathrm{~cm}$ であった.一方, 身長と MAP との 関係における第 1 変移点に相当する身長は, 男子で $139.8 \mathrm{~cm}$ ，女子では $138.8 \mathrm{~cm}$ であった .また，第

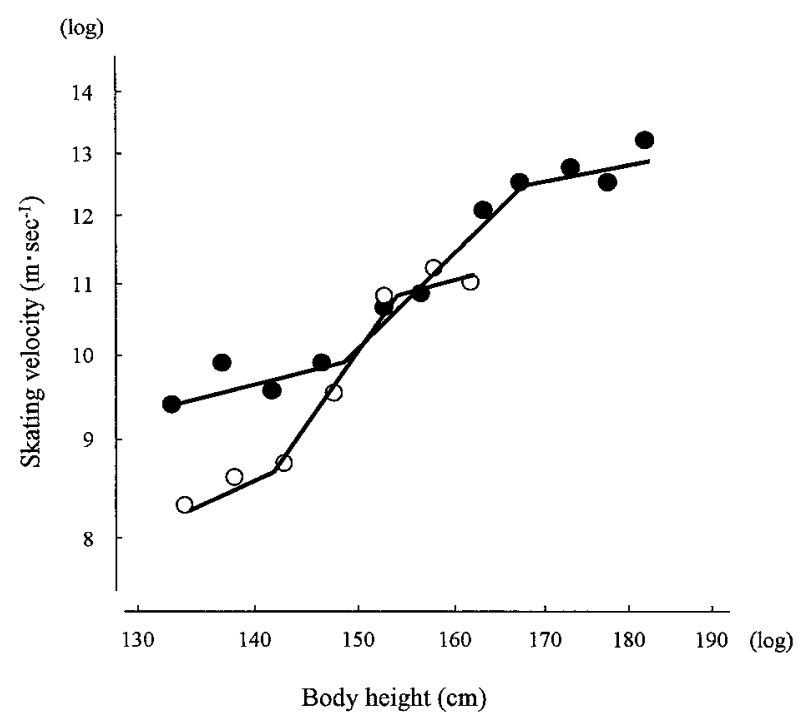

Fig. 4. The relationships between skating velocity and body height in male and female speed skaters. males. $\bigcirc$ : females.

2 変移点は男子の $166.8 \mathrm{~cm}$, 女子では $157.8 \mathrm{~cm}$ で 認められた . 身長と SV との関係における両変移点 間の身長範囲は，男子が $147.4 \mathrm{~cm}$ から $167.8 \mathrm{~cm}$ ， 女子は $142.2 \mathrm{~cm}$ から $153.2 \mathrm{~cm}$ であった .

D. アローメトリー式における係数“a” の変化 身長と筋厚との関係におけるアローメトリー式の 係数“a”の変化は, Fig. 5 に示した. 男子の MTA における係数“ a” は, 第 1 変移点を境に0.572から 3.265 に増加し, 第 2 変移点以降で 0.861 に減少し

Table 3. The first and second changing points of body height at which relationships between anterior and posterior thigh muscle thicknesses, maximal anaerobic power, skating velocity and body height in males and females.

\begin{tabular}{ccccccc}
\hline & \multicolumn{2}{c}{ Male } & & \multicolumn{2}{c}{ Female } \\
\cline { 2 - 3 } \cline { 5 - 6 } \cline { 5 - 6 } & \multicolumn{1}{c}{$\begin{array}{l}\text { First } \\
\text { changing point }\end{array}$} & $\begin{array}{l}\text { Second } \\
\text { changing point }\end{array}$ & & $\begin{array}{l}\text { First } \\
\text { changing point }\end{array}$ & $\begin{array}{l}\text { Second } \\
\text { changing point }\end{array}$ \\
\hline MTA & $152.2 \mathrm{~cm}$ & $168.1 \mathrm{~cm}$ & & $142.8 \mathrm{~cm}$ & $154.4 \mathrm{~cm}$ \\
MTP & $154.8 \mathrm{~cm}$ & $168.3 \mathrm{~cm}$ & & $144.9 \mathrm{~cm}$ & $157.6 \mathrm{~cm}$ \\
MAP & $139.8 \mathrm{~cm}$ & $166.8 \mathrm{~cm}$ & & $138.8 \mathrm{~cm}$ & $157.8 \mathrm{~cm}$ \\
SV & $147.4 \mathrm{~cm}$ & $167.8 \mathrm{~cm}$ & & $142.2 \mathrm{~cm}$ & $153.2 \mathrm{~cm}$ \\
\hline
\end{tabular}

MTA: Anterior thigh muscle thickness. MTP: Posterior thigh muscle thickness. MAP: Maximal anaerobic power. FFM : Fat free mass. ${ }^{*}$ indicates significant correlation coefficient $(p<0.05)$. 


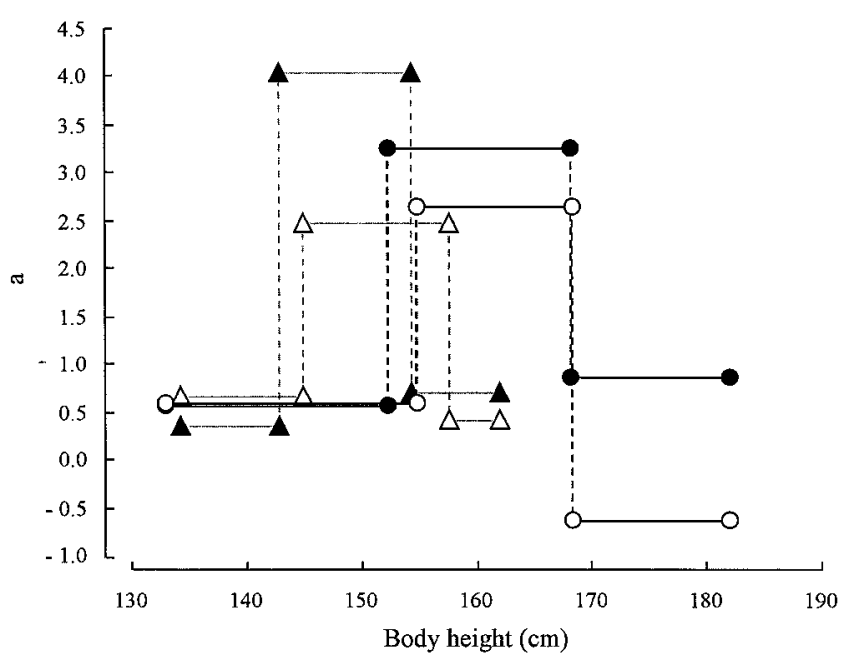

Fig. 5, The changes of index "a" in thigh muscle thicknesses with body height in male and female speed skaters. : Anterior thigh muscle thickness in males. $\bigcirc$ : Posterior thigh muscle thickness in males. Anterior thigh muscle thickness in females. $\triangle$ : Posterior thigh muscle thickness in females.

た . 同樣の傾向は女子の MTA についても認められ た.即ち，第 1 変移点で0.349から4.025に増加し， 第 2 変移点以降に0.690に減少した。また, MTPに おける係数“a”についても同樣に, 第 1 変移点を 境に男子は 0.592 から $2.637 に$ ，女子では0.648から 2.465 に増加し，第 2 変移点でー0.639及び0.407に それ光れ減少した。

Fig. 6 には身長と MAP との関係における係数 “a”の值を男女で示した. 両者の関係における係数 “a”は, 第 1 変移点を境に 1.712 から 6.706 (男子)及

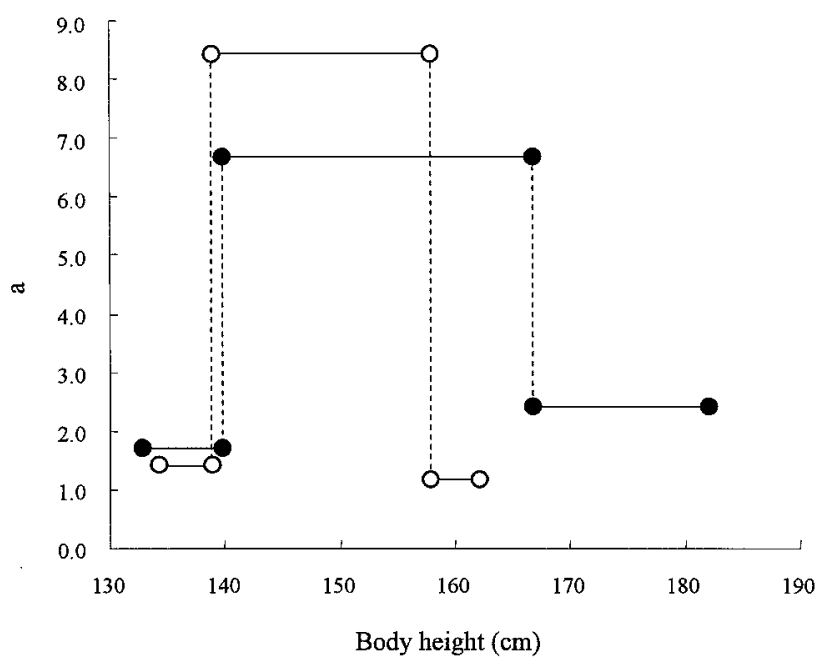

Fig. 6. The changes of index "a" in maximal anaerobic power with body height in male and female speed skaters. : Males. $\bigcirc$ : Females.

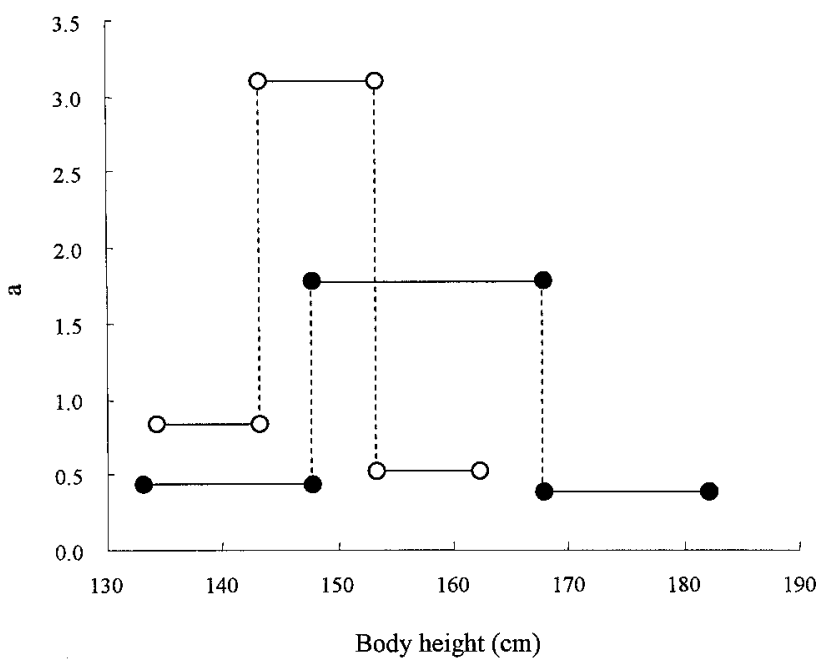

Fig. 7. The changes of index "a" in skating velocity with body height in male and female speed skaters.

: Males. $\bigcirc$ : Females.

び1.437から8.417(女子)に増加するものの, 第 2 変 移点以上では男子で2.429及び女子では1.181に乥れ 減少した。

身長と SV との関係における係数“a”は, 男子 で0.427から1.748に増加し，第 2 変移点を境に0.381 に減少した .女子の第 1 変移点における係数“a” の増加は0.835から3.103であり, 第 2 変移点以降で は0.527に減少した(Fig. 7) .

$$
\text { N. 考察 }
$$

A. 大腿部の筋厚及び無酸素性パワーと滑走能力 との関係

スピードスケート滑走中において筋の発揮する出 力は, 空気抵抗及び水とブレードとの摩擦抵抗に抗 して身体を前方に移動させるために用いられる ${ }^{29)}$. 従って, 競技成績の改善にはより多くの筋出力が必 要であると考えられており，これまでに骨格筋の形 態とスピードスケート滑走能力との関係を検討した 研究が多くなされている ${ }^{5,18,20)}$. これらの報告で は，国内の一流スピードスケート選手における競技 成績と除脂肪体重との間に高い相関関係が認められ ており, 競技能力向上のためにはより大きな除脂肪 体重が必要であることが指摘されている．本研究で は, MTA 及びMTPとSVとの間に, 弚れ光れ有 意な相関関係が認められたことから，スケート滑走 動作の主働筋である大腿筋群の量(筋厚)は, 男女と も滑走能力に直接的に関わることが示唆された . 方，下肢の筋出力と滑走能力に関して根本たち ${ }^{19)}$ 
は, 等速性の膝伸展筋出力とスピードスケート競技 成績との間に有意な相関関係が認められたことか ら, 競技能力の向上には単発的な筋の収縮力を高め ることの重要性を示唆している。また, van Ingen Schenau and de Groot ${ }^{28)}$ や Geijsel et al. ${ }^{6)}$ は成人の スピードスケート選手では, 自転車ペダリングによ り測定した無酸素性パワーがスピードスケート競技 能力に関連することを報告している. 即ち, 本研究 において MAP と SV との間に有意な相関係数が認 められた結果は，これらの報告を支持するものとい える.

また 本研究では, 筋厚に比べて最大無酸素パワー のほうが滑走速度との相関係数が高い值を示した . 一般に筋厚や筋横断面積は力を反映する因子である ことは周知の事実である . 一方 , 最大パワーは力と 速度の掛け合わせによって決定される . スピードス ケートの場合, 滑走速度はストロークの長さと単位 時間当たりのストローク数(ストローク頻度)により 決定される . de koning ${ }^{2)}$ は，スピードスケート滑走 中のスケートに作用する垂直方向の力を測定し，滑 走速度との関係を調べた結果, 両者の関係は統計学 的に有意ではないことを明らかにしており, 滑走速 度は1ストローク中に発揮される力ではなくスト ローク頻度によって決定されると考察している．従 つて, 筋力に加えて, 競技力に対する脚の動作速度 の貢献度も高いものと推察でき, 弚のことが本研究 における MAP と SV の関係で高い相関係数が認め られた結果の一要因として考えられる .

\section{B. 身長の発育に伴う筋厚及び無酸素性パワーの}

\section{発達}

身長は, 骨の発達度合いの指標として発育・発達 研究においてよく用いられている.このうち思春期 中の生徒を対象として, 身長の発育に及ぼすスポー ツトレーニングの影響について検討した Wanne and Valimäki ${ }^{30)}$ によると，思春期のトレーニングは 骨の発育に影響がないことを指摘している．また， スピードスケート選手と一般生徒における身長の年 齢推移を比較した Nemoto et al. ${ }^{23)}$ や根本たち ${ }^{21)} の$ 報告では，いずれの年齢段階ともに両者間の身長に は有意な差異は認められていない．これらの報告 は, スピードスケートのトレーニングが身長に及ぼ す影響が少ないことを示唆しており, 本研究の被検
者についても，一般児童及び生徒とほぼ同樣の身長 を有しているものと考えられる．

日本人青少年における体肢筋断面積と身長の関 係についてアローメトリー式を用いて検討した金久 たち ${ }^{10)}$ によれば，両者の関係は男女ともに 3 相の 直線で表され，係数“a”が最も高い值を示す身長 区間は, 男子が $152.1 \sim 153.2 \mathrm{~cm}$ から $163.1 \mathrm{~cm}$ $165.9 \mathrm{~cm}$ ，女子では $140.4 \mathrm{~cm} \sim 142.0 \mathrm{~cm}$ から 148.9 $\mathrm{cm} \sim 150.2 \mathrm{~cm}$ の範囲であったという. 本研究に おける MTA 及び MTP と身長の関係についても， 2 箇所の変移点を持つ 3 相の直線が認められ, 係 数“a”が最も高い值を示したのは両変移点間であつ た .このように，スピードスケート選手における筋 厚と身長の関係は，筋厚の急増区間を含む 3 相で示 されることが明らかになった . 先の金久たちの報告 によれば，身長と体肢筋断面積との関係において， 筋断面積の急増区間が男子は約12歳から16歳，女子 では約10歳から14歳であり，いずれも第二次性徵期 に相当する年齢で認められている．本研究における 筋厚の急増区間に相当する年齢は, 男子は約 13.0 歳 から16.4歳,女子では約11.0歳から約14.1歳であり， 先の報告とほぼ一致していた . 従って, 筋厚の発達 スパートの要因としては, 自然発育による筋量の増 加によるものと推察できる . また , 本研究において 発達のスパートか開始される第 1 変移点に相当する 身長についても，一般の男女の場合とほぼ同樣であ った ${ }^{10)}$. 即ち, 本研究のスピードスケート選手に おける大腿部の筋厚の発達スパートは, 一般の青少 年とほぼ同樣の身長で開始されていることが考えら れる.熊川 ${ }^{14)}$ は，群馬県嬬恋地区で実践されてい るスピードスケート選手のトレーニング内容につい て報告している．この報告によると，小学生後期( 4 年〜 6 年生)は, 走・跳・投能力といった基礎的な 身体活動能力の向上及びローラースケートによるス ケーティング技術の習得がねらいとして構成されて おり，ウエイトトレーニング等の筋肥大を目的とし たトレーニングは中学生以降から開始されている . 従って, 筋厚発達のスパート開始は, スピードスケ ートトレーニングの効果か現れたものと解釈するよ りも，むしろ自然発育によってもたらされる要素が 強いものと考えられる．一方，係数“a”の值が低 下する第 2 変移点に相当する身長は, 男女ともに先 の報告よりも高い身長(男子が $168.1 \mathrm{~cm} \sim 168.3$ 
$\mathrm{cm}$ ，女子では $154.4 \mathrm{~cm} \sim 157.6 \mathrm{~cm})$ で認められた . このことは, スピードスケート選手における筋厚の 急増区間が，一般生徒及び児童の光れよりも長いこ とを意味している . 従来, 筋力トレーニングの効果 は思春期以降において大きいことが報告されてい る. Nemoto et al. ${ }^{23)}$ は, ジュニア選手の筋量や筋出 カが, 男女ともに16歳以降の年齢で一般生徒よりも 有意に高い値を示すことから，思春期後のトレーニ ングが肢筋群の形態的及び機能的発達を促進する 可能性を指摘している. 本研究における筋厚值の年 齢変化についても, 男女ともに16歳以降で増加する 傾向がみられている.また, 本研究の身長と筋厚の 関係では, 第 2 変移点となる身長に該当する年齢 が, 男女ともに約16歳であった . さらに, 先の熊 川 ${ }^{14)}$ の報告によれば, 高校生期における体力面の トレーニングは, ウエイトトレーニングが中心とな り，徹底した筋力アップを目的に実施されている． 従って，これらの事を考慮すると本研究のスピード スケート選手における大腿筋群の発達スパート期が 一般生徒より長い要因としては，特に発育後期にお ける筋カトレーニング量の増加及びトレーニング効 果が大きいことに起因するのかもしれない．

スピードスケート滑走能力に関わる筋の機能的特 性の一つとして, 無酸素性作業能力が考えられてい る. 根本 ${ }^{22)}$ は, 無酸素性パワー及び全身の筋量の 指標である除脂肪体重と $500 \mathrm{~m}$ 平均滑走速度の間 には光れ午れ高い相関係数が認められたことから， 両者は密接な関係にあることを報告している . 同樣 の結果は, 本研究における SV と筋厚及び MAP の 相関係数からも確かめられた . また, Mercier et al. $^{15)}$ は11歳から19歳の男子について, Dore et al. ${ }^{4)}$ は，16歳から18歳の男女を対象として下肢の体積を 算出し, 自転車全力ペダリング中のピークパワーと の関係を乥れ光れ検討した結果，いずれの報告とも に両者間には高い相関係数か認められている.従っ て, 筋厚と無酸素性パワーの発育は同樣の推移を 示すことが予想された . 本研究における MAP と身 長の関係は, 男女ともに 3 相の直線で表され, 係数 “a”が最も高い值を示した身長区間は，筋厚におい てみられる区間と同樣の範囲内にあった . しかしな がら，MAP における第 1 変移点は, 男女ともに筋 厚の弚れよりも低い身長で認められた .このこと は, スピードスケート選手の無酸素性パワー発揮能
力は, 大腿部の筋形態よりも早い時期で発達のス パートが開始されることを意味するものである . 金 久たち ${ }^{8)}$ は, 7 歳から18歳の男女における膝伸展及 び屈曲筋群の断面積及び筋出力の年齢変化を明らか にしている．この報告では, 筋断面積及び筋出力の いずれの年齢変化についても, 男子では12歳以降に 増加の程度が増すが, 急増が開始される年齢は両項 目ともにほぼ同樣の年齢でみられている．また，本 研究における筋厚と MAP の年齢変化をみると, 男 子の MTP を除けば筋厚は10歳からの増加が大き く, MAP では男女ともに11歳から著しく増加する 傾向がみられている，従って，身長を基準とし，生 物学的な成熟度の差を除去してスピードスケート選 手の体力的要素の発達を考えた場合, トレーニング の効果か現れるのは, パワー発揮能力のほうが筋量 (筋厚)よりも早い可能性が考えられる.

\section{C. 身長の発育に伴う滑走能力の発達}

本研究では, 身長の発育にともなう滑走速度の発 達について検討した . Asmussen and HeeboollNielsen ${ }^{1)}$ は, ディメンジョン論の観点から, 速度 と身長の関係におけるアローメトリー式の係数“ a” は，理論的には“0”であると報告している．従っ て，速度は身長に規定されない項目であるというこ とになる。しかし，この報告における走速度一身長 関係の係数“a”は，0.677であり，理論値と一致し ていない、本研究における SV $(\mathrm{y})$ と身長 $(\mathrm{x})$ の関係 についても，全ての局面において“0”を上回る結 果となった . 先行研究 ${ }^{1)}$ では, このような理論値と 実測値のズレの要因として, 神経系の発達による運 動動作自体の発達を挙げている . 従って, 滑走能力 の発達には, Asmussen and Heebooll-Nielsen ${ }^{1)}$ の示 す lineal dimension 以外の, 滑走技術や身体組織の 質的な変化及び心理状態等が影響を及ぼすものと考 えられる.また, 本研究における SV と身長の関係 で係数“ a”が“ 1”を上回る身長区間は両変移点間 であり，他の局面では男女とも“1”を下回る結果 となった .このことは, 第1変移点前及び第 2 変移 点後では, 身長に対して滑走能力の発育が下回り, 男子の身長約 $147 \mathrm{~cm}$ から $167 \mathrm{~cm}$ 及び女子の約 143 $\mathrm{cm}$ から $153 \mathrm{~cm}$ の区間においてのみ, 滑走能力の 発達が優位であることを意味するものである . 従っ て本研究の結果から, 滑走能力についても思春期発 
育によるものと思われる急増区間が存在することが 考えられる .

一方, MAP と SV の変移点に相当する身長を比 較すると, SV における第 1 変移点は MAP よりも 高い身長でみられた . 即ち, 水上滑走能力は無酸素 性パワー発揮能力よりも急増の開始する時期が遅い といえる . 根本 ${ }^{18)}$ は, 膝関節伸展筋力とスピード スケート競技成績との相関係数が, 中学生及び高校 生期において高く，乥れ以降及び以前の年齢では低 い值を示すことを報告している．また，熊川たち ${ }^{12)}$ は，身長を基準として男子スピードスケート選手 を思春期前，思春期中及び思春期後の 3 群に分け， $500 \mathrm{~m}$ 平均滑走速度とスライドボード上での動作速 度の相関関係を群別に明らかにしている. 兴の結 果, 最も高い相関係数を示したのは思春期中に相当 する時期であり，思春期前の選手では両者の間に有 意な相関関係は存在しない事を報告している．これ らの報告は, 競技成績に対する最大パワー発揮能力 の貢献度が年代によって異なる可能性を示してお り，特に思春期前においては炎の影響が少ないもの と推察できる. 従って, 本研究における SV の発達 スパートの初期段階においては, 滑走能力に対する 最大パワー発揮能力の貢献度が小さいことが予想さ れ，弚のことが本研究の結果の一要因として考えら れる.

$$
\text { V.結論 }
$$

本研究では, 身長の発育に伴うスピードスケート 滑走能力の発達と大腿部の筋厚及び無酸素性パワー 発揮能力との関係について検討した . 兴の結果, 以 下のことが明らかになった .

1) 大腿部の筋厚と滑走速度との相関関係から, 子 供から成人のスピードスケート選手における大 腿筋群の量は競技成績に直接的に関わることが 示唆された。

2) 大腿部の筋厚に比べて無酸素性パワーのほうが 競技能力との関係が強いことが明らかになっ た .このことから，筋力に加えて，競技力に対 する脚の動作速度の貢献度も高いことが考えら れた .

3) スピードスケート選手の身長と筋厚の関係は 3 相で表され，筋厚発達のスパートは自然発育に よる要素が強いことが考えられた。ただし, 筋
厚発達のスパート終了時における身長がこれま での報告に比べて高く，特に思春期後における 筋カトレーニングの影響が強いことが考えられ た。

4) 滑走能力の発達スパートが開始される身長は, 筋厚のスパート開始身長に比べて低く，無酸素 性パワーの光れよりも高かった . 従って, 思春 期前では滑走能力と大腿部の筋量及び無酸素性 パワーの発達か㳔応していないことが考えられ た。

\section{(受理日 平成19年11月21日)}

\section{参 考 文 献}

1) Asmussen E. and Heebooll-Nielsen K. A., dimensional analysis of physical performance and growth in boys. J. Appl. physiol., ( 1955), 7, 593-603.

2) de Koning J. J., Power equation for speed skating. Int. J. sport biomech., (1987), 103-109

3) de Koning J. J., Bakker F. C., de Groot G., van Ingen Schenau G. J., Longitudinal development of young talented speed skaters: physiolosical and anthropometric aspects. J. Appl. Physiol., (1994), 77, 23112317.

4) Dore E., Martin R., Ratel S., Duche P., Bedu M., van Praagh E., Gender differences in peak muscle per. formance during growth. Int. J. Sports Med., (2005), 26, 274-28.

5) 江橋 博,西嶋洋子, 今泉哲雄, 一木昭男, 松尾彰文, 福永哲夫，女子スピード・スケート選手の体力特性 一橋本聖子選手について一, 体力研究, (1990)，76, $1-16$.

6) Geijsel J., Bomhoff G., van Velzen J., de Groot G., van Ingen Schenau G. J., Bicycle ergometry and speed skating performance. Int. J. Sports Med., (1984), 5 , 241-245.

7）石田良恵，金久博昭，福永哲夫，中村栄太郎，日本 人一流競技選手の皮下脂肪厚と筋厚，Jpn. J. Sports Sci., (1992)，11，587-596.

8) 金久博昭，福永哲夫，角田直也，池川繁樹，発育期 青少年の単位筋断面積当たりの筋力，体力科学， (1985)，34，71-78.

9）金久博昭，福永哲夫，池川繁樹，石田良恵，陸上競 技(短·中·長距離)，バレーボールおよびスピード・ スケート選手の筋断面積における性差, Jpn. J. Sports Sci., (1986)， 5, 662-668.

10）金久博昭，角田直也，池川繁樹，福永哲夫，相対発 育からみた日本人青少年の筋断面積. 人類学雑誌, (1989) , 97:63-70.

11) Kanehisa H., Nemoto I., Okuy ama H., Ikegawa S., Fukunaga T., Force generation capacity of knee extensor muscle in speed skaters. Eur. J. Appl. Physiol., 
(1996), 73, 544-551.

12) 熊川大介, 田中重陽, 熊川輝男, 青葉貴明, 角田直也, 男子スピードスケート選手における身長からみた相 対発育が筋形態, スライド動作速度及び滑走能力に 及ぼす影響, 東京体育学研究2003年度報告, (2004)， $53-56$.

13) 熊川大介, 角田直也, 男女スピードスケート選手に おける下肢筋群の形態及びパワー発揮能力に及ぼす 競技種目の影響，トレーニング科学，(2006)，18， 241-249.

14) 熊川輝男, 成長期スピードスケート選手のトレーニ ング，トレーニング科学，(1991)，3，7-11.

15) Mercier B., Mercier J., Granier P., Le Gallais D., Prefaut C., Maximal anaerobic power : Relationship to anthropometric characteristics during growth. Int. J. Sports Med., (1992), 13, 21-26.

16) 宮下充正, カナダのスポーツ選手の体力を測る, Jpn. J. Sports Sci., (1985) , 4, 591-597 .

17) 森下はるみ, 日本人青少年の形態発育と機能発育の 解析的研究, 体育学研究, (1966)，11，47-58.

18) 根本 勇, 速く滑る一スピード・スケート一, Jpn. J. Sports Sci., (1983) , 2 , 921-934.

19) 根本 勇, 入沢孝一, 吉岡伸彦, 金久博昭, 宮下充正, スピード・スケート選手の等速性筋出力と競技成績 との関係, デサントスポーツ科学 , (1984), 5, 206212 .

20) 根本 勇, 吉岡伸彦, 船渡和男, 岩岡研典, 宮下充正, 日本人五輪候補スピード・スケート選手の身体組成， Jpn. J. Sports Sci., (1986) , 5, 501-506.

21) 根本 勇, 金久博昭, 宮下充正, 形態及び筋出力と その持続能力の年齢推移に及ぼすスポーツ・トレー ニングの影響, 疲労と休養の科学, (1987),2,79-96.
22) 根本 勇, スピードスケート競技力の科学, トレー ニング科学 , (1992) , 14, 111-119.

23) Nemoto I., Kanehisa H., Miyashita M., The effect of sports training on the age-related changes of body composition and isokinetic peak torque in knee extensors of junior speed skaters. J. Sports Med. Phys. Fitness, (1990), 30, 83-88.

24) Pollock M. L., Foster C., Anholm J., Hare J., Farrell P., Maksud M., Jackson A. S., Body composition of Olympic speed skating candidates. Res. Q. Exerc. Sport, (1982), 53, 150-155.

25) Rajala G. M., Neumann D. A., Foster C., Jensen R. H., Quadriceps muscle performance in male speed skaters. J. Strength Cond. Res., (1994), 8, 48-52.

26) 角田直也, 金久博昭, 福永哲夫, 近藤正勝, 池川繁樹, 大腿四頭筋断面積における各種競技選手の特性, 体 力科学，(1986)，35，192-199.

27 ) van Ingen Schenau G. J., de Groot G., Hollander A. P., Some technical, physiological and anthropometrical aspects of speed skating. Eur. J. Appl. Physiol., (1983a), 50, 343-354.

28) van Ingen Schenau G. J. and de Groot G., Difference in oxygen consumption and external power between male and female skaters during supramaximal cycling. Eur. J. Appl. Physiol., (1983b), 51, 337-345.

29) van Ingen Schenau G. J., de Boer R. W., de Groot G., On the technique of speed skating. Eur. J. Appl. Phy siol., (1987), 3, 419-431.

30) Wanne $O$. and Valimăki I., The influence of sports training on growth in school children. Scand. J. Sports Sci., (1983), 5, 41-44. 